\title{
A generalized nonlinear tempeature response function for some growth and developmental parameters in kiwifruit (Actinidia deliciosa (A. Chev.) C. F. Liang \& A. R. Ferguson)
}

\author{
Função não linear de resposta à temperatura para alguns parâmetros \\ de crescimento e desenvolvimento em kiwi (Actinidia deliciosa (A. \\ Chev.) C. F. Liang \& A. R. Ferguson)
}

\section{Nereu Augusto Streck ${ }^{1}$}

\section{ABSTRACT}

Temperature is a major factor that affects metabolic processes in living organisms. Thermal time has been widely used to account for the effects of temperature on crop growth and development. However, the thermal time approach has been criticized because it assumes a linear relationship between the rate of crop growth or development and temperature. The response of the rate of crop growth and development to temperature is nonlinear. The objective of this study was to develop a generalized nonlinear temperature response function for some growth and developmental parameters in kiwifruit (Actinidia deliciosa (A. Chev.) C. F. Liang \& A. R. Ferguson). The nonlinear function has three coefficients (the cardinal temperatures), which were $0^{\circ} \mathrm{C}, 25^{\circ} \mathrm{C}$, and $40^{\circ} \mathrm{C}$. Data of temperature response of relative growth rate, relative leaf area growth, net photosynthesis rate, and leaf appearance rate in kiwifruit (female cv. Hayward) at two light levels, which are from published research, were used as independent data for evaluating the performance of the nonlinear and the thermal time functions. The results showed that the generalized nonlinear response function is better than the thermal time approach, and the temperature response of several growth and developmental parameters in kiwifruit can be described with the same response function.

Key words: temperature, model,growth, development, kiwifruit.

\section{RESUMO}

Temperatura é um dos principais fatores que afeta a velocidade das reações metabólicas em seres vivos. O método da soma térmica tem sido o mais usado para descrever o efeito da temperatura sobre o crescimento e desenvolvimento vegetal, mas este método tem recebido críticas, pois nele é assumido uma relação linear entre crescimento ou desenvolvimento vegetal e temperatura. A resposta do crescimento e desenvolvimento vegetal à temperatura é não linear. $O$ objetivo deste trabalho foi desenvolver uma função geral não linear de resposta à temperatura para alguns parâmetros de crescimento e desenvolvimento em kiwi (Actinidia deliciosa (A. Chev.) C. F. Liang \& A. R. Ferguson). A função não linear tem três coeficientes (as temperatures cardeais), que foram $0^{\circ} \mathrm{C}, 25^{\circ} \mathrm{C} e$ $40^{\circ} \mathrm{C}$. Dados independentes da taxa de crescimento relativo, taxa de expansão foliar relativa, taxa de fotossíntese líquida e taxa de aparecimento de folhas em kiwi (cv. feminina Hayward), em diferentes temperaturas e dois níveis de densidade de fluxo de radiação fotossinteticamente ativa, oriundos da literatura, foram usados para avaliar a função não linear e o método da soma térmica. Os resultados mostraram que a função não linear é superior ao método da soma térmica e que a resposta à temperatura de diferentes parâmetros de crescimento e desenvolvimento em kiwi pode ser estimada com a mesma função matemática.

Palavras-chave: temperatura, modelo, crescimento, desenvolvimento, kiwi.

\section{INTRODUCTION}

Kiwifruit (Actinidia deliciosa (A. Chev.) C. F. Liang \& A. R. Ferguson) is a dioecious (i.e., requires both the female cultivar and a suitable pollenizer to supply a large quantity of viable pollen) deciduous

${ }^{1}$ Engenheiro Agrônomo, Professor Adjunto, Departamento de Fitotecnia, Centro de Ciências Rurais, Universidade Federal de Santa Maria, 97105-900, Santa Maria-RS, Brasil. E-mail: nstreck1@ smail.ufsm.br. 
warm-temperate perennial vine crop (BRUNDELL, 1975). It is an important crop in a selected number of countries that export most of their production, New Zealand being the largest exporter, followed by Italy and Chile (HASEY et al., 1994). The high commercial value of the fruit is associated with its flavor and high vitamin C content, which is at least twice that of orange (HASEY et al., 1994). Kiwifruit also has the potential of being an important crop in Southern Brazil, where climatic conditions are favorable for this crop.

Crop simulation models offer a conceptual framework for the organization of research as well as are valuable application tools for yield forecast, policy analysis, decision-making activities, crop management practices, and selection of appropriate cultivars in breeding programs. Horticulture is characterized by a high diversity of cultivation systems, and fruit, vegetable and ornamental species, but so far only few of them have been modeled (GARY et al., 1998).

Despite the large variation in types, complexity, and levels of organization, crop simulation models have in common a growth and a development sub-models. Growth refers to the accumulation of biomass, length, area, or volume. Development refers to the differentiation and initiation of organs. These two sub-models are independent but function in synchronism, because the partitioning of assimilates to different organs is greatly dependent upon plant developmental stage. Therefore, the accurate description of growth and developmental processes is important for the success of any crop simulation model.

Among growth parameters, relative growth rate (RGR), relative leaf area growth (RLAG), and net photosynthesis rate $(\mathrm{Pn})$ are frequently used in crop simulation models and they have operational definitions (PENNING de VRIES et al., 1989; GOUDRIAN \& van LAAR, 1994). The RGR is defined as the rate of change of dry matter per actual accumulated dry matter, and it has dimensions of [(MASS) $\left.\left(\mathrm{MASS}^{-1}\right)\left(\mathrm{TIME}^{-1}\right)\right]$. The RLAG is defined as the rate of change of leaf area per actual leaf area, and has dimensions of [(LENGTH $\left.{ }^{2}\right)$ $\left.\left(\mathrm{LENGTH}^{-2}\right)\left(\mathrm{TIME}^{-1}\right)\right]$. Net photosynthesis rate can be on a leaf area or on a leaf weigh basis, having dimensions of [(MASS) $\left.\left(\mathrm{LENGTH}^{-2}\right)\left(\mathrm{TIME}^{-1}\right)\right]$ or [(MASS) $\left(\mathrm{MASS}^{-1}\left(\mathrm{TIME}^{-1}\right)\right]$, respectively.

An important developmental parameter in crop simulation models is the leaf appearance rate (LAR) (HODGES, 1991; WANG \& ENGEL, 1998). The LAR is the time rate that leaves appear on a culm or vine and has dimensions of [(1) $\left.(\text { TIME })^{-1}\right)$. The integration of LAR over time gives the number of emerged leaves on each culm or vine, which is an excellent measure of plant development. The number of leaves is related to the expansion of leaf area and light interception by the canopy, and therefore, canopy photosynthesis, which in turn is related to the accumulation of dry matter and commercial yield.

Virtually all the metabolic processes in living organisms are temperature-dependent. As a consequence, temperature affects almost all aspects of plant growth and development. The first quantitative study of plant-temperature relationship is attributed to René A. F. de Réaumur around 1730 (RÉAUMUR, 1735). Since then, the concept of heat units, or thermal time, has been widely used to describe the temperature response in plants and insects (see WANG, 1960; ARNOLD, 1960; PRUESS, 1983 for detailed reviews).

Thermal time is attractive and convenient because it is simple and it vastly improves the prediction of plant temperature-related processes under field conditions compared to other time descriptors such as time of the year or number of days after sowing (GILMORE \& ROGERS, 1958; RUSSELE et al., 1984; McMASTER \& SMIKA, 1988). In its simplest way, thermal time is calculated by accumulating the number of degrees above a base or threshold temperature $\left(\mathrm{T}_{\text {base }}\right)$ in a linear fashion, either on an hourly $\left({ }^{\circ} \mathrm{C} \mathrm{h}^{-1}\right)$ or on a daily basis $\left({ }^{\circ} \mathrm{C}\right.$ day $\left.^{-1}\right)($ McMASTER \& SMIKA, 1988).

The thermal time approach, however, has been criticized because it assumes a linear relationship between the rate of biological processes and temperature (WANG, 1960; McMASTER \& WILHELM, 1997). The response of biological systems to temperature is linear in only a portion of the temperature range that affects biological processes, and is better summarized in terms of three cardinal temperatures, namely the minimum $\left(\mathrm{T}_{\text {min }}\right)$, optimum $\left(\mathrm{T}_{\mathrm{opt}}\right)$, and maximum $\left(\mathrm{T}_{\max }\right)$ temperatures (JONES, 1992; SHAYKEWICH, 1995). In this paper, $T_{\min }$ is differentiated from $T_{\text {base }}$ to refer to nonlinear and thermal time approaches, respectively. The rates of simple chemical reactions increase exponentially with increasing temperature, starting at $\mathrm{T}_{\text {min }}$, following an Arrhenius-type equation (ARRHENIUS, 1889). Biological reactions, however, have an optimum temperature, with reaction rates declining at temperatures above $\mathrm{T}_{\text {opt }}$. The primary reason for the decline in the reaction rate at supraoptimal temperatures is that most biological reactions are enzyme catalyzed. At high temperatures, the catalytic properties of most enzymes are harmed and the total amount of enzyme present may fall as a result of increased rates of denaturation, and the reaction rate decreases to zero at $T_{\max }$ (SHARPE \& DeMICHELE, 1977). Therefore, close to $T_{\min }$ and $T_{\text {opt }}$, the response of biological processes to temperature is nonlinear (SHAYKEWICH, 1995). 
To minimize the empiricism of the simplest approach to calculate thermal time, some authors proposed an upper threshold at $\mathrm{T}_{\text {opt }}$ (GILMORE \& ROGERS, 1958; WANG, 1960; McMASTER \& SMIKA, 1988). A further refinement of the thermal time approach includes a linear decrease of the rate of the process from a maximum value at $\mathrm{T}_{\text {opt }}$ to zero at $\mathrm{T}_{\max }(\mathrm{KINIRY} \&$ BONHOMME, 1991; BAKER et al., 2001). These modifications of the original way to calculate thermal time, however, are still not enough to overcome the empiricism of the approach because it is composed of a combination of linear equations, which introduces abrupt changes at the transition points of the response function. The response of plant processes to temperature is smooth and continuous, which can cause a significant departure from the linearity (SHAYKEWICH, 1995). The thermal time approach has also other disadvantages: (i) it is confusing how people implement the calculation of thermal time on a daily basis, i.e., sometimes the average daily temperature is subtracted from $\mathrm{T}_{\text {base }}$ and sometimes the minimum and maximum temperatures are subtracted from $\mathrm{T}_{\text {base }}$ and then averaged (McMASTER \& WILHELM, 1997); (ii) it lacks generality because either the end points of the function, defined by $\mathrm{T}_{\text {base }}, \mathrm{T}_{\mathrm{opt}}$, and $\mathrm{T}_{\max }$, or the total number of ${ }^{\circ} \mathrm{C}$ for completing a given process or developmental phase are often dependent on genotype, and for many genotypes these values are unknown (McMASTER \& SMIKA, 1998; KINIRY \& BONHOMME, 1991).

To overcome the criticism of the thermal time approach, nonlinear temperature response functions have been introduced in models of several field crops (HORIE, 1994; WANG \& ENGEL, 1998; JAME et al., 1999). Nonlinear functions also introduce elegant and smooth responses in the model. In this new approach, the temperature response function [f(T)] varies from 0 to 1 and is multiplied by the maximum rate of the process being modeled, which is attained under optimum environmental conditions. When the temperature departs from $\mathrm{T}_{\mathrm{opt}}$, the actual rate decreases as a function of $\mathrm{f}(\mathrm{T})$. However, a literature search showed that thermal time is still being used in models of horticultural crops, including kiwifruit (e.g. MORLEY-BUNKER \& SALINGER, 1987; LESCOURRET et al., 1998, 1999). This comprises a rationale for developing a nonlinear temperature response function in kiwifruit models.

The objective of this study was to develop a generalized nonlinear temperature response function for some growth and developmental parameters in kiwifruit. A nonlinear function is more realistic that the thermal time approach from a biological point of view, and a generalized function for different growth and developmental parameters reduces the number of input data in kiwifruit simulation models.

\section{MATERIALANDMETHODS}

A typical biological response to temperature from $\mathrm{T}_{\min }$ to $\mathrm{T}_{\mathrm{opt}}$ follows a logistic curve (SHAYKEWICH, 1995). The response increases slowly as temperature increases from $\mathrm{T}_{\min }$, it increases in a linear fashion at intermediate temperatures, and the rate of increase decreases as temperature approaches $\mathrm{T}_{\mathrm{opt}}$, where the response is at a maximal. At temperatures above $T_{\text {opt }}$, the response decreases and eventually ceases at $T_{\max }$. The beta function used by WANG \& ENGEL (1998), to describe the response of development to temperature in wheat (Triticum aestivum L.), was used in this study to describe the temperature response of RGR, RLAG, $\mathrm{Pn}$, and LAR in kiwifruit. The temperature function $[\mathrm{f}(\mathrm{T})]$ varies from 0 to 1 and is defined as:

$$
\begin{aligned}
f(T) & =\left[2\left(T-T_{\min }\right)^{a}\left(T_{o p t}-T_{\min }\right)^{a}-\left(T-T_{\min }\right)^{2 a}\right] /\left(T_{o p t}-T_{\min }\right)^{2} \\
a & =\ln 2 / \ln \left[\left(T_{\max }-T_{\min }\right) /\left(T_{\text {opt }}-T_{\min }\right)\right]
\end{aligned}
$$

where $\mathrm{T}, \mathrm{T}_{\mathrm{opt}}$, and $\mathrm{T}_{\max }$ are the cardinal temperatures (minimum, optimum, and maximum). Equation (1) is a flexible curve and, by changing the cardinal temperatures, it can attain several shapes. The temperature response of some biological processes using eq. (1) is represented in figure 1 . The vernalization response of winter wheat has cardinal temperatures of $-1^{\circ} \mathrm{C}, 5^{\circ} \mathrm{C}$, and $16^{\circ} \mathrm{C}$ (PORTER \& GAWITH, 1999). The response of seedling growth rate in maize (Zea mays L.) has cardinal temperatures of $0^{\circ} \mathrm{C}, 32^{\circ} \mathrm{C}$, and $43^{\circ} \mathrm{C}$ (YAN \& HUNT, 1999). In defining the cardinal temperatures for RGR, RLAG, Pn, and LAR in kiwifruit, it was assumed that $\mathrm{T}_{\min }$ is $0^{\circ} \mathrm{C}, \mathrm{T}_{\mathrm{opt}}$ is $25^{\circ} \mathrm{C}$, and $\mathrm{T}_{\text {max }}$ is $40^{\circ} \mathrm{C}$. The assumption of a minimum temperature of $0^{\circ} \mathrm{C}$ was because this value has worked well for both winter crops like wheat (WANG \& ENGEL, 1998) and summer crops like maize, sorghum (Sorghum bicolor (L.) Moench), bean (Phaseolus vulgaris L.), and lambsquarters (Chenopodium album L.) (YAN \& HUNT, 1999). A value of $25^{\circ} \mathrm{C}$ for $\mathrm{T}_{\text {opt }}$ was selected because most temperate $\mathrm{C}$ plants have maximum growth at this temperature (PENNING DE VRIES et al., 1989). The assumption of a maximum temperature of $40^{\circ} \mathrm{C}$ was based on HASEY et al. (1994) who showed that photosynthesis in kiwifruit drops rapidly as temperature reaches $38^{\circ} \mathrm{C}$. Therefore, the function to describe the temperature response of RGR, RLAG, Pn, and LAR in kiwifruit was:

$$
f(T)=\left[2(T)^{a}(25)^{a}-(T)^{2 a}\right] /(25)^{2 a}
$$

Ciência Rural, v. 33, n. 2, mar-abr, 2003. 
with $\mathrm{a}=1.47477$. The response curve generated with eq. (3) is plotted in figure 1 .

The thermal time function used in kiwifruit models (MORLEY-BUNKER \& SALINGER, 1987; LESCOURRET et al., 1998, 1999) was also used in this study as a comparison with eq. (3). These kiwifruit models use $\mathrm{a}_{\text {base }}=7.5^{\circ} \mathrm{C}$ for the thermal time function and no $\mathrm{T}_{\mathrm{opt}}$ and $\mathrm{T}_{\max }$ is assumed, i.e., the thermal time is accumulated over $\mathrm{T}_{\text {base }}$ without an upper threshold. The assumption of no upper threshold value in the thermal time is not realistic, and for a fair comparison with eq. (3), the thermal time function was considered to have $\mathrm{T}_{\text {base }}=7.5^{\circ} \mathrm{C}, \mathrm{T}_{\mathrm{opt}}=25^{\circ} \mathrm{C}$, and $\mathrm{T}_{\max }=40^{\circ} \mathrm{C}$.

In order to test the performance of eq. (3) and the thermal time approach, independent data of growth parameters RGR $\left(\mathrm{g} \mathrm{g}^{-1}\right.$ day $\left.^{-1}\right), \operatorname{RLAG}\left(\mathrm{cm}^{2} \mathrm{~cm}^{-2}\right.$ day $\left.^{-1}\right)$, and $\mathrm{Pn}\left(\mathrm{mg} \mathrm{CO} \mathrm{g}^{-1} \mathrm{~s}^{-1}\right)$, and the developmental parameter LAR (leaves day ${ }^{-1}$ ) in kiwifruit at five temperatures $\left(10^{\circ} \mathrm{C}, 15^{\circ} \mathrm{C}, 20^{\circ} \mathrm{C}, 25^{\circ} \mathrm{C}\right.$, and $\left.30^{\circ} \mathrm{C}\right)$ and two photosynthetic photon flux densities (PPFD $=650$ $\mathrm{mmol} \mathrm{m} \mathrm{s}^{-2}$, and PPFD $=280 \mathrm{mmol} \mathrm{m}^{-2} \mathrm{~s}^{-1}$ ) reported in the literature were used. These data are from experiments in controlled-environment rooms carried out at Palmerston North, New Zealand. The growth and developmental parameters data are of the female cultivar Hayward, the most widely commercially grown kiwifruit cultivar worldwide (HASEY et al., 1994). The

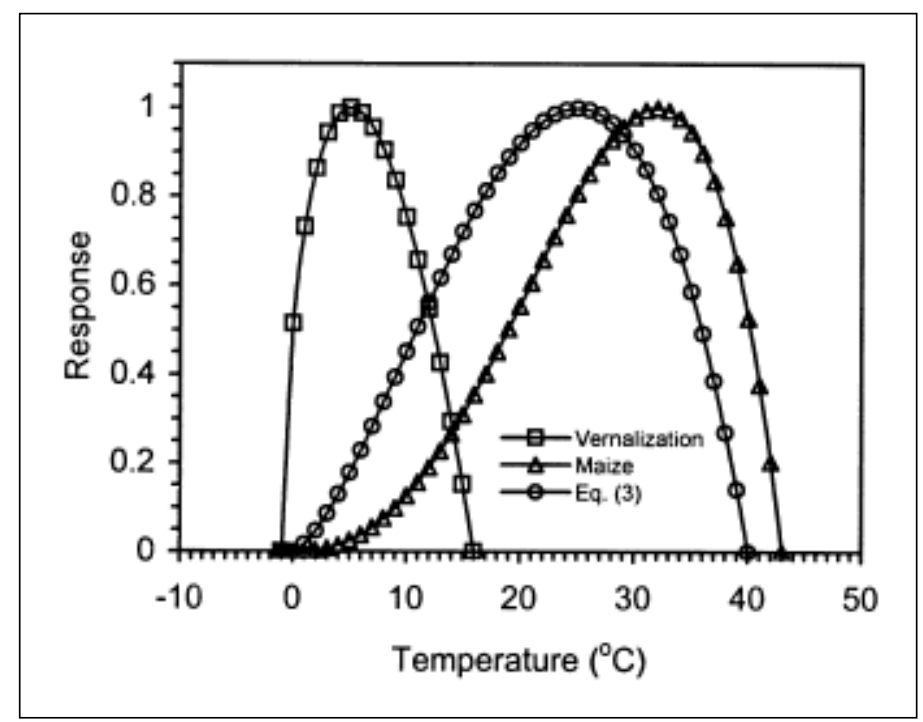

Figure 1 - The beta function (eq. 1) describing the temperature response of three plant processes: the vernalization response of winter wheat (Triticum aestivum L.) with $\mathrm{T}_{\min }=-1^{\circ} \mathrm{C}, \mathrm{T}_{\mathrm{opt}}=5^{\circ} \mathrm{C}$, and $\mathrm{T}_{\max }=16^{\circ} \mathrm{C}$, the response of seedling growth rate in maize (Zea mays L.) with $\mathrm{T}_{\min }=0^{\circ} \mathrm{C}, \mathrm{T}_{\text {opt }}=32^{\circ} \mathrm{C}$, and $\mathrm{T}_{\max }=43^{\circ} \mathrm{C}$, and the growth and developmental response in kiwifruit (Actinidia deliciosa (A. Chev.) C. F. Liang \& A. R. Ferguson) with $\mathrm{T}_{\min }=0^{\circ} \mathrm{C}, \mathrm{T}_{\mathrm{opt}}=25^{\circ} \mathrm{C}$, and $\mathrm{T}_{\max }=40^{\circ} \mathrm{C}$ (eq. 3). data of RGR, RLAG, and LAR were taken from MORGAN et al. (1985), and Pn from LAING (1985). Data of Pn are only at high PPFD in the original paper. Growth parameters data were presented in Tables in the original papers. The LAR data were extracted from a Figure in the original paper, which was enlarged to minimize random errors of interpolation. In all cases, data were normalized to vary from 0 to 1 by dividing each value by the maximum value, which was either at 20 or $25^{\circ} \mathrm{C}$.

The temperature response predicted both with eq. (3) and with the thermal time function was compared with the observed values of the growth and developmental parameters in each temperature. The statistic used for evaluating the model performance was the root mean square error (RMSE), calculated as (JANSSEN \& HEUBERGER, 1995):

$\mathrm{RMSE}=\left[\mathrm{S}\left(\mathrm{P}_{\mathrm{i}}-\mathrm{O}_{\mathrm{i}}\right)^{2} / \mathrm{N}\right]^{0.5}$

where $\mathrm{P}=$ predicted data, $\mathrm{O}=$ observed data, $\mathrm{N}=$ number of observations, and $\mathrm{i} \stackrel{\mathrm{i}}{=} 1 \ldots \mathrm{N}$. The model with the lowest RMSE is the best.

\section{RESULTS AND DISCUSSION}

The observed data of growth and developmental parameters (RGR, RLAG, Pn, and LAR) of the kiwifruit female cv Hayward grown at different temperatures and two light intensities, and the temperature response curve predicted with eq. (3) and with the thermal time function are presented in figure 2.

The observed data show a maximum response in the range of $20-25^{\circ} \mathrm{C}$ and a decrease when temperature departs from $\mathrm{T}_{\mathrm{opt}}$. Also, the observed data, as they were normalized with respect to their maximum, all fall into a similar pattern of response to temperature at both PPFD levels, suggesting a general type of response for different growth and developmental parameters.

Photosynthesis is very sensitive to temperature, with both physical and biochemical limitations playing a role to decrease Pn at sub- and supra-optimal temperatures (PENNING de VRIES et al., 1989; JONES, 1992). An increase in $P n$ as temperature increases from $T_{\min }$ to $T_{\text {opt }}$ is a result of an increase in either one or both stomatal and mesophyll conductance to $\mathrm{CO}_{2}$, and an increase in the activity of the enzyme ribulose 1,5-bisphosphate carboxylase

Ciência Rural, v. 33, n. 2, mar-abr, 2003. 
(Rubisco) with temperature (LUDLOW \& WILSON, 1971; JONES, 1992). A decline in Pn as temperature increases from $T_{\text {opt }}$ to $T_{\max }$ is associated with a decrease in either one or both stomatal and mesophyll conductance to $\mathrm{CO}_{2}$ with temperature (LUDLOW \& WILSON, 1971), a rapid increase in dark respiration (and in $\mathrm{C}_{3}$ plants, like kiwifruit, photorespiration as well) with temperature (JACKSON \& VOLK, 1970), and an inactivation of Rubisco at supra-optimal temperatures (JONES, 1992). Another reason why Pn decreases at supra-optimal temperatures in $\mathrm{C}_{3}$ plants is that the solubility of $\mathrm{CO}_{2}$ decreases relatively faster than the solubility of $\mathrm{O}_{2}$, causing a unbalance between carboxylase and oxigenase activities of Rubisco, which leads to an $\mathrm{O}_{2}$ inhibition at the carboxylation site that decreases Pn (LAING et al., 1974; EHLERINGER \& BJÖRKMAN, 1977; KU \& EDUARDS, 1977). Other growth parameters like RGR and RLAG are largely dependent upon Pn (but not only), and therefore show a temperature response similar to the $\mathrm{Pn}$ response to temperature. Leaf area expansion is also dependent on cell division, which is also temperature-sensitive (JONES, 1992). The appearance of leaves is a result of other processes such as leaf initiation, and cell division and growth, which are also very sensitive to temperature (KIRBY, 1990; HAY \& KIRBY, 1991).

e observed data in figure 2 also show that a linear response occurs only at intermediate temperatures $\left(10^{\circ} \mathrm{C}-20^{\circ} \mathrm{C}\right)$. Close to the optimum temperature $\left(25^{\circ} \mathrm{C}\right)$, the response is nonlinear. This trend was captured by the beta function (eq. 3), which had an excellent performance over the entire range of observed data (RMSE was 0.05 and 0.04 at high and low PPFD, respectively). The performance of the thermal time approach, however, was not good (RMSE was 0.26 and 0.25 at low and high PPFD, respectively), with under prediction of most of the observed data except when the temperature is optimum (Figure 2). Note that, in addition to the linear response, a value of $\mathrm{T}_{\text {base }}=7.5^{\circ} \mathrm{C}$, commonly used for kiwifruit (MORLEYBUNKER \& SALINGER, 1987; LESCOURRET et al., 1998, 1999), is also not an appropriate assumption in the thermal time approach (Figure 2). The $\mathrm{T}_{\text {base }}$ in the thermal time function was also set to $0^{\circ} \mathrm{C}$, but even then the response was under predicted (data not shown), with RMSE of 0.16 and 0.15 at high and low PPFD, respectively, indicating that eq. (3) is still better.

Response functions used in crop simulation models are usually different for different processes (PENNING de VRIES, 1989). This is often a problem, because the coefficients of the functions are unknown. Occam's Razor is encouraged in crop modeling (SINCLAIR \& MUCHOW, 1999), i.e., the simplest theory is preferred to more complex ones or explanations of phenomena should be in terms of

Ciência Rural, v. 33, n. 2, mar-abr, 2003. 
known quantities. Therefore, the search for generalized response functions is a major goal in crop modeling. As shown in this study, the response of different growth and developmental parameters to temperature in kiwifruit can be described by a generalized nonlinear function.

Several reasons contribute to adopt eq. (3) as a generalized temperature function for growth and development in kiwifruit. Firstly, the coefficients (the cardinal temperatures) have biological meaning. Secondly, eq. (3) is a robust and general function, as the cardinal temperatures $\left(\mathrm{T}_{\min }, \mathrm{T}_{\mathrm{opt}}\right.$, and $\left.\mathrm{T}_{\max }\right)$ were derived from independent studies and different species. Thirdly, eq. (3) was a better predictor of the temperature response of different growth and developmental parameters at two different PPFD levels than the existing approach (thermal time). Fourthly, the function (eq. 3) describes what is currently accepted in terms of temperature response of biological systems (SHAYKEWICH, 1995). At temperatures close to $T_{\min }$, the response is close to 0 , the response increases in a linear fashion at intermediate temperatures, the response reaches a maximum when temperature approaches $\mathrm{T}_{\mathrm{opt}}$, and the response decreases afterwards to 0 at $T_{\max }$. Fifthly, the response of eq. (3) is more realistic than the thermal time approach (Fig. 2). Biological systems are more likely to respond to environmental factors in a smooth and continuous fashion rather than in a combination of linear functions that introduce abrupt changes in the response (SHAYKEWICH, 1995).

The assumption of $\mathrm{T}_{\min }=0^{\circ} \mathrm{C}$ in eq. (3) was reasonable for kiwifruit. The assumption of $\mathrm{a} \mathrm{T}_{\min }=0^{\circ} \mathrm{C}$ has been successfully used in models of other winter and summer crops (WANG AND ENGEL, 1998; YAN \& HUNT, 1999). $\mathrm{A} \mathrm{T}_{\text {base }}=7.5^{\circ} \mathrm{C}$ for kiwifruit, however, seems to be not appropriate, even though it has been used in kiwifruit models (MORLEY-BUNKER \& SALINGER, 1987; LESCOURRET et al., 1998, 1999). A $\mathrm{T}_{\text {base }}=10^{\circ} \mathrm{C}$ was used for grape vine (Vitis vinifera $\mathrm{L}$.), a species grown in similar seasons and with similar growth habit (GITTEREZ et al., 1985; SHULTZ, 1992). Defining correct values of cardinal temperatures for plant processes in different species and cultivars is often a constraint in crop modeling. For example, in an extensive literature review, PORTER \& GAWITH (1999) attempted to summarize values of cardinal temperatures for wheat, but the results were frustrating as for several growth and development processes only values greater than or lower than a certain value are presented, or the range presented for each cardinal temperature is of several degrees. More studies aiming to determine the cardinal temperatures in different species, including kiwifruit, would be very useful for modelers.
Crop simulation models are incomplete tools and errors in the predictions are still quite frequent, including in kiwifruit models (LESCOURRET et al., 1998, 1999). The responses of some basic plant processes to environmental factors are still poorly described in crop simulation models, and, from the results obtained here, the temperature response of growth and developmental parameters in kiwifruit (using thermal time) is one among them. The fact that the nonlinear response function presented in this paper was a better predictor of the response of growth and developmental parameters to temperature in kiwifruit compared to the thermal time approach strongly suggests that the performance of kiwifruit models can be improved. This hypothesis is open to be tested.

\section{CONCLUSION}

A generalized nonlinear temperature response function is better than the thermal time approach, and the temperature response of several growth and developmental parameters in kiwifruit can be described with the same response function. The cardinal temperatures of $0^{\circ} \mathrm{C}, 25^{\circ} \mathrm{C}$, and $40^{\circ} \mathrm{C}$ are reasonable approximations for the nonlinear response function in kiwifruit.

\section{ACKNOWLEDGEMENTS}

The author is grateful to the Conselho Nacional de Desenvolvimento Científico e Tecnológico (CNPq), of the Ministry for Science and Technology of Brazil, for the financial support during this study (Proc. n. 200010/98-0).

\section{REFERENCES}

ARNOLD, C.Y. Maximum-minimum temperatures as a basis for computing heat units. Proceedings of the American Society for Horticultural Science, Boston, v.76, n.1, p.682692, 1960.

ARRHENIUS, S. Uber die reactions geschwindigkeit bei der inversion von rohrzuker durch sauren. Annals of Physics and Chemistry, London, v.4, n.1, p.226-248, 1889.

BAKER, J.T. et al. A simple phenological model of muskmelon development. Annals of Botany, London, v.87, n.5, p.615$621,2001$.

BRUNDELL, D.J. Flower development of the Chinese Gooseberry (Actinidia Chinensis). I. Development of the flowering shoot. New Zealand Journal of Botany, Wellington, v.13, n.2, p.473-483, 1975.

EHLERINGER, J., BJÖRKMAN, O. Quantum yields for $\mathrm{CO}_{2}$ uptake in $\mathrm{C}_{3}$ and $\mathrm{C}_{4}$ plants. Plant Physiology, Baltimore, v.59, n.1, p.86-90, 1977.

Ciência Rural, v. 33, n. 2, mar-abr, 2003. 
GARY, C.; JONES, J.W.; TCHAMITCHIAN, M. Crop modeling in horticulture: state of the art. Scientia Horticulturae, Amsterdam, v.74, n.1, p.3-20, 1998

GILMORE, E.C.Jr.; ROGERS, J.S. Heat units as a method of measuring maturity in corn. Agronomy Journal, Madison, v.50, n.10, p.611-615, 1958

GITTEREZ, A.P.; WILLIAMS, D.W.; KIDO, H. A model of grape growth and development: the mathematical structure and biological considerations. Crop Science, Madison, v. 25, n. 5 , p. $721-728,1985$

GOUDRIAN, J.; van LAAR, H.H. Modeling potential crop growth processes. Dordrecht: Kluwer Academic, 1994. 238p.

HASEY, J.K. et al. Kiwifruit: growing and handling. Oakland : University of California, Division of Agriculture and Natural Resources, 1994. 134p.

HAY, R.K.M.; KIRBY, E.J.M. Convergence and synchrony - a review of the coordination of development in wheat. Australian Journal of Agricultural Research, Melbourne, v.42, n.5, p.661-700, 1991.

HORIE, T. Crop ontogeny and development. In: BOOTE, K.J. et al. Physiology and determination of crop yield. Madison: ASA/CSSA/SSSA, 1994. Cap.7, p.153-180.

HODGES, T. Predicting crop phenology. Boca Raton CRC, 1991. 233p.

JACKSON, W.A.; VOLK, R.J. Photorespiration. Annual Review of Plant Physiology, Palo Alto, v.21, n.1, p.385432, 1970.

JAME, Y.M.; CUTFORTH, H.W.; RITCHIE, J.T. Temperature response function for leaf appearance rate in wheat and corn. Canadian Journal of Plant Science, Ottawa, v.79, n.1, p.1-10, 1999.

JANSSEN, P.H.M.; HEUBERGER, P.S.C. Calibration of processoriented models. Ecological Modelling, Amsterdam, v.83, n.1, p.55-56, 1995

JONES, H.G. Plants and microclimate. 2 ed. New York : Cambridge University, 1992. 428p.

KINIRY, J.R.; BONHOMME, R. Predicting maize phenology. In: HODGES, T. Predicting crop phenology. Boca Raton : CRC, 1991. Cap.11, p.115-132.

KIRBY, E.J.M. Co-ordination of leaf emergence and leaf and spikelet primordium initiation in wheat. Field Crops Research, Amsterdam, v.25, n.3-4, p.253-264, 1990.

KU, S.B.; EDWARDS, G.E. Oxygen inhibition of photosynthesis. I. Temperature dependence and relation to $\mathrm{O} /$ CO solubility ratio. Plant Physiology, Baltimore, v.549 n.5, p. $986-990,1977$.

LAING, W.A. Temperature and light response curves for photosynthesis in kiwifruit. (Actinidia chinensis). New Zealand Journal of Agricultural Research, Wellington, v.28, n.1, p.117-124, 1985.

LAING, W.A.; OGREN, W.L.; HAGEMAN, R.H. Regulation of soybean net photosynthesis $\mathrm{CO}_{2}$ fixation by the interaction of $\mathrm{CO}_{2}, \mathrm{O}_{2}$, and ribulose 1,5-diphosphate carboxylase. Plant Physiology, Baltimore, v.54, n.5, p.678-685, 1974.

LESCOURRET, F. et al. Pollination and fruit growth models for studying the management of kiwifruit orchards. I. Model description. Agricultural Systems, Amsterdam, v.56, n.1, p.67-89, 1998.

LESCOURRET, F. et al. Development of a simulation model for studying kiwifruit orchard management. Agricultural Systems, Amsterdam, v.59, n.2, p.215-239, 1999.

LUDLOW, M.M.; WILSON, G.L. Photosynthesis of tropical pasture plants. I. Illuminance, carbon dioxide concentration, leaf temperature, and leaf-air vapor pressure difference. Australian Journal of Biological Sciences, Melbourne, v.24, n.3, p.449-470, 1971.

McMASTER, G.S.; SMIKA, D.E. Estimation and evaluation of winter wheat phenology in the central Great Plains. Agricultural and Forest Meteorology, Amsterdam, v.43, n.1, p.1-18, 1988 .

McMASTER, G.S.; WILHELM, W.W. Growing degree-days: one equation, two interpretations. Agricultural and Forest Meteorology, Amsterdam, v.87, n.4, p.291-300, 1997.

MORGAN, D.C.; WARRINGTON, I.J.; HALLIGAN, E.A. Effect of temperature and photosynthetic photon flux density on vegetative growth of kiwifruit (Actinidia chinensis). New Zealand Journal of Agricultural Research, Wellington, v.28, n.1, p.109-116, 1985.

MORLEY-BUNKER, M.J.; SALINGER, M.J. Kiwifruit development: the effect of temperature on bud burst and flowering. Weather and Climate, Wellington, v.7, n.1, p.2630, 1987.

PENNING de VRIES, F.W.T. et al. Simulation of ecophysiological processes of growth in several annual crops. Wageningen : Pudoc, 1989. 271p.

PORTER, J.R.; GAWITH, M. Temperatures and the growth and development of wheat: a review. European Journal of Agronomy, Amsterdam, v.10, n.1, p.23-36, 1999.

PRUESS, K.P. Day-degree days methods for pest managements. Environmental Entomology, College Park, v.12, n.3, p.613619, 1983

RÉAUMUR, R.A.F. de. Observation du thermometer, faites à Paris pendant l'année 1735, compares avec celles qui ont été faites sous la ligne, à l'Isle de France, à Alger et en quelques-unes de nos isles de l'Amérique. Paris: Mémoires de l'Académie des Sciences, 1735. 545p.

RUSSELE, M.P. et al. Growth analysis based on degree days. Crop Science, Madison, v.24, n.1, p.28-32, 1984.

SHARPE, P.J.H.; DeMICHELE, D.W. Reaction kinetics of poikilotherm development Journal of Theoretical Biology, London, v.64, n.4, p.649-670, 1977.

SHAYKEWICH, C.F. An appraisal of cereal crop phenology modeling. Canadian Journal of Plant Science, Ottawa, v.75, n.2, p.329-341, 1995.

Ciência Rural, v. 33, n. 2, mar-abr, 2003. 
SHULTZ, H.R. An empirical model for the simulation of leaf appearance rate and leaf area development of primary shoots of several grapevine (Vitis vinifera L.) canopy-systems. Scientia Horticulturae, Amsterdan, v.52, n.3, p.179-200, 1992.

SINCLAIR, T.R.; MUCHOW, R.C. Occam's Razor, radiation use efficiency and and vapor pressure. Field Crops Research, Amsterdam, v.62, n.2-3, p.239-243, 1999.

WANG, J.Y. A critique of the heat unit approach to plant response studies. Ecology, Durham, v.41, n.4, p.785-790, 1960.

WANG, E.; ENGEL, T. Simulation of phenological development of wheat crops. Agricultural Systems, Amsterdam, v.58, n.1, p.1-24, 1998.

YAN, W.; HUNT, L.A. An equation for modeling the temperature response of plants using only cardinal temperatures. Annals of Botany, London, v.84, n.5, p.607-614, 1999. 